\title{
SITUS-SITUS ARKEOLOGI DI DAERAH GEGUNUNG SEBAGAI JEJAK PERMUKIMAN AWAL DI CIREBON
}

\section{Archaeological Sites in Gegunung Area as The Early Settlement in Cirebon}

\author{
Nanang Saptono ${ }^{1)}$ dan Endang Widyastuti ${ }^{2)}$ \\ Balai Arkeologi Jawa Barat \\ Jl. Raya Cinunuk Km. 17, Cileunyi, Bandung \\ 1) E-mail: nanangsaptono@gmail.com \\ ${ }^{2)}$ E-mail: endangwidyastuti6@gmail.com
}

Naskah diterima: 27 September 2019 Revisi terakhir: 07 November 2019

Disetujui terbit: 05 Desember 2019 - Tersedia secara online: 17 Desember 2019

\begin{abstract}
Since a period of Hindu-Buddhist influence, Cirebon region has been an important area, although geographically not as a government center. The existence of the Huludayeuh inscription shows that the area was noticed by the rulers of the Sunda Kingdom. When the Sunda Kingdom suffered a setback and Muslim communities on the coast developed to form political power, the southern region of Cirebon flourished. One of the developing settlements is the Gegunung Village on the edge of Ci Pager. This study shows some archaeological objects in the area. The results of this study are expected to be used as input for policy decisions in the management of ancient relics. In Gegunung Village there are several petilasan as an early sign of the emergence of settlements. Based on oral traditions, the emergence and development of these settlements began with a border guard post.
\end{abstract}

Keywords: site, petilasan, settlement

\begin{abstract}
Abstrak
Kawasan Cirebon sejak masa pengaruh Hindu-Buddha sudah merupakan kawasan penting, meskipun jauh dari pusat pemerintahan. Keberadaan prasasti Huludayeuh menujukkan kawasan itu diperhatikan oleh penguasa Kerajaan Sunda. Ketika Kerajaan Sunda mengalami kemunduran dan masyarakat muslim di pesisir berkembang membentuk kekuatan politik, di kawasan Cirebon selatan berkembang. Salah satu permukiman yang berkembang adalah Desa Gegunung di tepi Ci Pager. Kajian ini menampilkan beberapa objek arkeologis di daerah itu. Hasil kajian ini diharapkan dapat dijadikan bahan masukan bagi penentuan kebijakan dalam hal pengelolaan tinggalan purbakala. Di Desa Gegunung terdapat beberapa petilasan sebagai tanda awal munculnya permukiman. Berdasarkan tradisi lisan, muncul dan berkembangnya permukiman tersebut diawali dari adanya pos penjagaan tapal batas.
\end{abstract}

Kata kunci: situs, petilasan, permukiman

\section{PENDAHULUAN}

Wilayah Cirebon merupakan salah satu kawasan di Jawa Barat yang memiliki sejarah budaya sejak dari masa prasejarah hingga sekarang. Beberapa tinggalan arkeologis yang memberikan ciri budaya dari masing-masing masa tersebut telah banyak ditemukan. Di Kelurahan Gegunung, Kecamatan Sumber, Kabupaten Cirebon 
terdapat kawasan situs arkeologi yang belum diregistrasi. Sementara itu, perhatian terhadap peninggalan arkeologis di Cirebon sudah dilakukan sejak zaman pemerintah kolonial. Pada masa itu wilayah Kabupaten Cirebon masih meliputi Kuningan dan Majalengka. Oudheidkundige dienst in Nederlandsch Indie pada tahun 1914 telah melakukan inventarisasi terhadap tinggalan-tinggalan arkeologis di kawasan Cirebon. Di wilayah distrik Losari pernah ditemukan kapak batu dan batu menyerupai arca di Cigobang, dekat Ci Losari. Di Dampiang ditemukan arca durga dari bahan batu. Di Distrik Losari pernah ditemukan jambangan kecil berisi duabelas cincin dan sebuah gelang besi. Di Palimanan pernah ditemukan pahat batu. Sebuah cincin emas juga pernah ditemukan di sawah di Desa Pilangsari, Distrik Gegesiklor (Krom, 1915).

Pada tahun 1991 di Desa Cikalahang, Kecamatan Sumber ditemukan prasasti batu berhuruf Jawa Kuna berbahasa Sunda Kuna. Berdasarkan berita temuan tersebut pada tahun 1992 Pusat Penelitian Arkeologi Nasional Jakarta melakukan serangkaian penelitian di situs Prasasti Huludayeuh. Prasasti Huludayeuh terdiri dari 11 baris, isinya antara lain menyebut tentang seorang yang bergelar Sri Maharaja dari Kerajaan Pakwan. Dengan adanya prasasti tersebut menunjukkan bahwa daerah Cirebon merupakan wilayah Kerajaan Pakwan Pajajaran (Djafar, 1994: 198).

Pada tahun 1993/1994 tim dari Balai Arkeologi Bandung mengadakan penelitian di daerah Cirebon. Dalam penelitian tersebut di antaranya telah dicatat beberapa situs antara lain situs Balong, Gunung Singkil, Gunung Lumpang, dan situs "Arca Semar". Di situs Balong terdapat kolam pemandian. Di belakang kolam terdapat lahan bekas pasanggrahan yang dikelilingi tembok bata. Di situs Gunung Singkil terdapat prasasti beraksara Cina. Di situs "Arca Semar” yang selanjutnya disebut dengan situs Pejambon, terdapat beberapa arca diantaranya adalah Siwa, Ganesa, ular, dan lingga yoni. Meskipun arca-arca tersebut menunjukkan berlatar belakang agama Hindu, namun bentuk arca-arca tersebut berbeda dengan aturan ikonografis Hindu pada umumnya (Suhadi dan Saptono, 1994). Selanjutnya Endang Widyastuti mengkaji keberadaan arcaarca di Pejambon tersebut. Di situs Pejambon terdapat 27 arca. Beberapa arca merupakan arca baru hasil karya Bapak Cayat. Arca-arca baru menggambarkan ular dengan berbagai variasi. Arca-arca kuna menampilkan atribut kuat sebagai Siwa bertangan empat, Ganeça, Durga, dan sosok punakawan. Selain itu juga terdapat lingga dan yoni (Widyastuti, 2002).

Beberapa objek purbakala di kawasan Cirebon selatan pernah diinventarisir oleh Dinas Pariwisata dan Kebudayaan Provinsi Jawa Barat (Sunarto, Saptono, Boedi, dan Rif'ati, 2011). Situs-situs tersebut selain situs Huludayeuh dan Pejambon juga terdapat kawasan situs Pasir Paniis, Keramat Plangon, Balong Tuk, dan situs Cirebon Girang. Pasir Paniis merupakan kawasan perbukitan memanjang yang secara administratif termasuk di wilayah Kampung Nagrak, Desa Sedong Kidul, Kecamatan Sedong. Di kawasan ini pernah ditemukan beberapa fosil stegodon, cervus, bovidae, ikan hiu, dan beberapa fosil moluska yang tidak teridentifikasi. Keramat Plangon merupakan salah satu objek purbakala dari zaman Islam. Di keramat ini terdapat makam Pangeran Panjunan dan Pangeran Kejaksan. Lokasi Keramat Plangon secara administratif 
termasuk di wilayah Desa Babakan, Kecamatan Sumber. Di Kampung Tuk, Desa Tuk, Kecamatan Kedawung terdapat balong (kolam) mata air. Di Desa Cirebon Girang, Kecamatan Talun, Kabupaten Cirebon, Jawa Barat, terdapat keramat Mbah Kuwu Sangkan. Kompleks keramat tersebut merupakan situs petilasan padepokan milik guru Kuwu Sangkan yang bernama Resi Danuwarsih. Pada sekitar tahun 1447 padepokan tersebut ditinggalkan dan berdiri perkampungan. Kuwu Sangkan kemudian memerintahkan Pangeran Cerbon untuk menata dan membangun pemerintahan di situ dan berdirilah Pakuwon Cirebon Girang sebagai cikal bakal Kesultanan Cirebon.

Sehubungan dengan sejarah kawasan Cirebon selatan terutama pada masa awal penyebaran Islam, terdapat beberapa tinggalan purbakala yang patut diduga sebagai situs cagar budaya di kawasan Pasarean, Kelurahan Gegunung, Kecamatan Sumber. Berdasarkan hal itu perlu dilakukan pendataan awal terhadap objek-objek tersebut. Tujuan pendataan awal ini untuk memberikan bahan masukan bagi registrasi objekobjek peninggalan sejarah dan arkeologi agar selanjutnya dapat ditetapkan sebagai cagar budaya.

Pendataan dilakukan dalam bentuk observasi permukaan disertai wawancara dengan informan. Pelaksanaan pendataan meliputi pendeskripsian dan pendokumentasian objek. Wawancara dengan informan dilakukan secara terbuka. Topik wawancara lebih dikhususkan pada pengumpulan data tradisi sejarah yang masih berkembang di masyarakat. Selain itu juga berbagai keterangan berkenaan dengan persoalan objek pendataan.

\section{HASIL DAN PEMBAHASAN \\ Riwayat Singkat Pangeran Pasarean}

Menurut tradisi lisan yang disampaikan oleh sesepuh petilasan Pangeran Pasarean, R. Hasan Ashari, Pangeran Pasarean mempunyai nama asli Pangeran Muhammad Arifin. Beliau adalah putra Syaikh Syarif Hidayatullah, atau yang dikenal dengan nama Sunan Gunung Jati. Pernikahan Sunan Gunung Jati dengan Nyimas Tepasari, putri Ki Ageng Tepasan dari kerajaan Majapahit menurunkan Pangeran Pasarean yang lahir pada tahun $1495 \mathrm{M}$.

Pada kurun 1528-1552, Sunan Gunung Jati melakukan perluasan wilayah kekuasan. Secara pribadi, Sunan Gunung Jati lebih mencurahkan perhatian pada penyebaran agama Islam. Sementara itu, urusan pemerintahan dipercayakan kepada Pangeran Pasarean. Tugas-tugas ini diemban hingga tahun 1546. Pada tahun itu Pangeran Pasarean wafat di Demak (Hardjasaputra dan Haris, 2011). Di antara tugas penting itu mengurus pemerintahan, Pangeran Pasarean diperintahkan membuat tapal batas antara Galuh dan Cirebon.

Dalam menjalankan tugas memastikan tapal batas, Pangeran Pasarean dikawal oleh pasukan dan pinisepuh berbekal senjata cis yaitu keris yang bentuknya menyerupai tombak. Pelaksanaan pembuatan tapal batas diawali dari daerah Mandirancan di kaki Gunung Ciremai. Beliau menancapkan senjata cisnya terus ke arah utara dan akhirnya sampailah di suatu daerah yang tanahnya ngegunduk menyerupai gunung yang sekarang 
dinamakan Gegunung. Di Gegunung Pangeran Pasaren dan rombongan dihadang oleh serombongan pasukan yang dipimpin oleh Sang Ikul Tua seorang telik sandi Kerajaan Pajajaran. Setelah tahu Pangeran Pasarean adalah putra mahkota Sunan Gunung Jati yang juga cicit Prabu Silihwangi maka Sang Ikul Tua kemudian tunduk pada Pangeran Pasarean.

Akhirnya Pangeran Pasarean dan para pengawalnya menetap di Gegunung untuk melaksanakan penyiaran agama Islam dan menggembleng dirinya dan pasukannya baik jasmani maupun rohani. Latihan ini dimaksudkan untuk persiapan menjadi pemimpin dan prajurit sejati yang mengutamakan kepentingan agama, bangsa, dan negara. Selain itu juga sering mengadakan pertemuan-pertemuan dengan mengundang para kigede dan tokoh-tokoh kesultanan untuk membahas strategi yang mengancam atau mengganggu Kesultanan Cirebon. Sang Ikul Tua sering kali memimpin rapat para tokoh kesultanan. Berkat pertimbangan beliau yang luhur hasil rapat selalu memuaskan semua pihak dan menghasilkan keputusan yang baik maka Sang Ikul Tua bergelar Ki Buyut Timbang Luhur.

Pada masa itu di Gegunung telah tersusun perangkat tugas dan tata kerja yang baik, sebagaimana organisasi pada masa kini. Pangeran Pasarean duduk sebagai pemimpin yang dibantu Ki Buyut Timbang dan Ki Buyut Pakualam sebagai Dewan Penasehat. Ki Logawa (Buyut Sena) dan Buyut Tambak sebagai pemangku keamanan. Sementara bagian perlengkapan dijabat Ki Buyut Srana, bagian dakwah Ki Buyut Kilaya, Ki Buyut Truna memimpin bidang Kepemudaan, Ki Buyut Pasindangan bertugas sebagai hakim pemutus perkara. Sampai sekarang makam-makam para pengageng tersebut masih terawat baik di Kelurahan Gegunung Kecamatan Sumber Kabupaten Cirebon.

Adapun lokasi tempat rapat-rapat diberi nama Pendopo Agung. Bekas goresan cis yang membentang dari selatan ke utara membentuk sungai yang diberi nama $\mathrm{Ci}$ Pager artinya air atau sungai pembatas. Sumur tempat air minum mandi dan wudlu diberi nama sumur Bagja Kamulyan. Tempat Pangeran bersemedi dan menyimpan benda-benda miliknya diberi tanda yang sekarang disebut keramat Pangeran Pasarean (Ashari, 2018).

\section{Gambaran Umum Lokasi}

Kabupaten Cirebon merupakan bagian dari wilayah Provinsi Jawa Barat yang terletak di bagian timur dan merupakan batas, sekaligus sebagai pintu gerbang Provinsi Jawa Tengah. Dalam sektor pertanian Kabupaten Cirebon merupakan salah satu daerah produsen beras yang terletak di jalur pantura.

Letak daratan memanjang dari Barat Laut ke Tenggara. Dilihat dari permukaan tanah/daratannya dapat dibedakan menjadi dua bagian, pertama daerah dataran rendah umumnya terletak di sepanjang pantai utara, yaitu Kecamatan Gegesik, Kaliwedi, Kapetakan, Arjawinangun, Panguragan, Klangenan, Gunungjati, Tengah Tani, Weru, Astanajapura, Pangenan, Karangsembung, Waled, Ciledug, Losari, Babakan, Gebang, Palimanan, Plumbon, Depok dan Kecamatan Pabedilan. Daerah-daerah lainnya 
merupakan daerah dataran tinggi.

Wilayah Kecamatan di sepanjang jalur pantura termasuk pada dataran rendah yang ketinggiannya antara $0-10 \mathrm{~m}$ dari permukaan air laut, sedangkan wilayah kecamatan yang terletak di bagian selatan berketinggian antara $11-130 \mathrm{~m}$ dari permukaan laut. Kecamatan Sumber berada di wilayah selatan. Geomorfologi berupa pedataran yang diselingi pedataran bergelombang dengan topografi miring ke arah utara. Kelurahan Gegunung berada di sebelah timur laut Kecamatan Sumber. Kawasan ini berada di antara dua aliran sungai. Di sebelah barat terdapat aliran Ci Pager yang mengalir dari arah selatan ke utara. Ci Pager berhulu di Desa Mandirancan lereng Gunung Ciremai. Di sebelah timur terdapat aliran $\mathrm{Ci}$ Kedungpane. Kelurahan Gegunung berbatasan dengan Kelurahan Pejambon di utara, Kelurahan Sindang di sebelah timur, Kelurahan Kemantren di selatan, dan Kelurahan Perbutulan di barat. Kawasan keramat Pangeran Pasarean berada di sebelah barat daya kantor Kelurahan Gegunung. Di lokasi keramat Pangeran Pasarean pada setiap hari Rabu terakhir pada bulan Safar menurut kalender Hijriah dilakukan tradisi Rebo Wekasan.

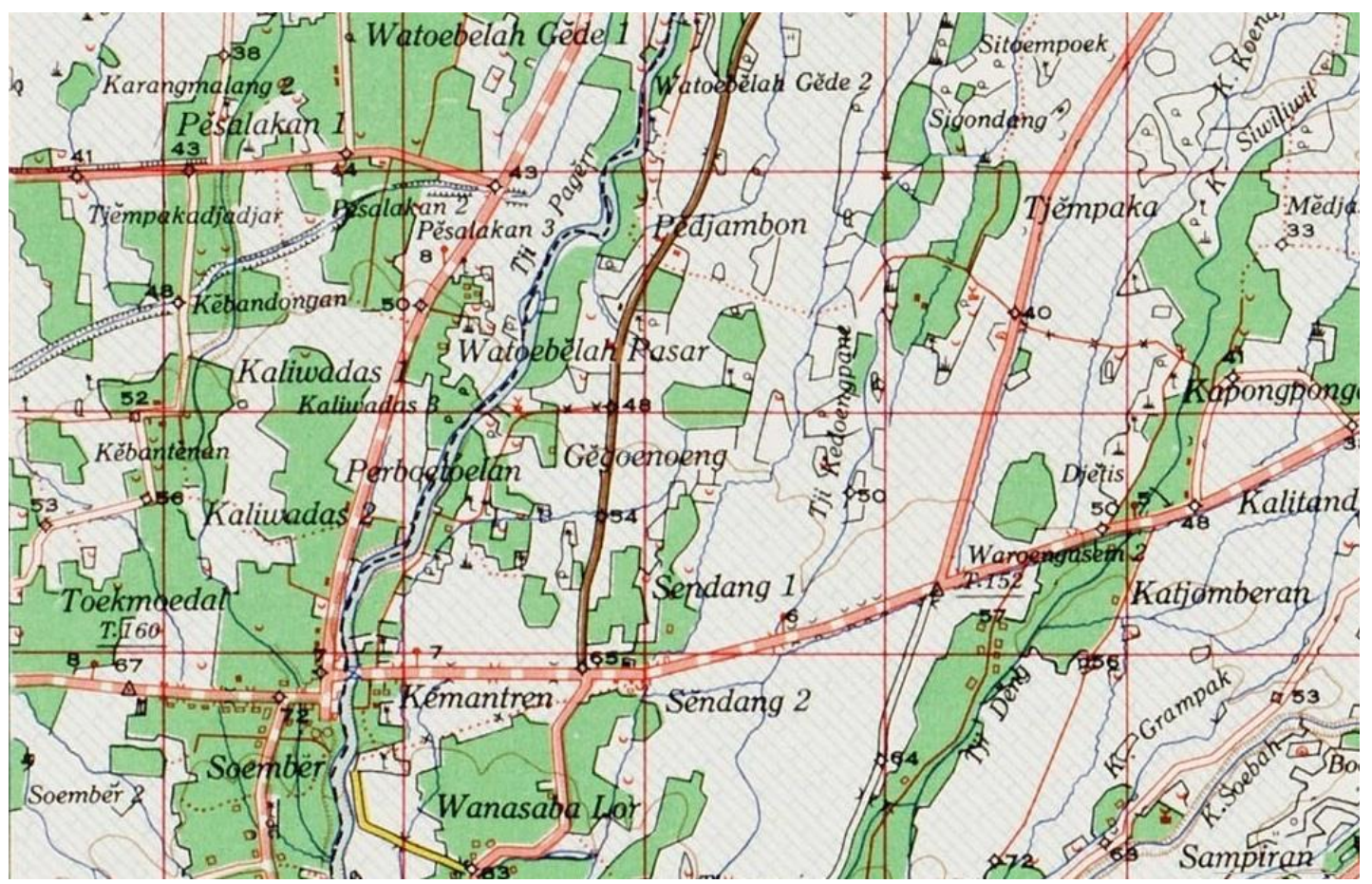

Gambar 1. Peta topografi wilayah Kelurahan Gegunung, Kecamatan Sumber, Kabupaten Cirebon (Sumber: Peta Topografi daerah Cheribon Sheet 42/XXXIX-A. Dutch Colonial maps. Leiden University)

\section{Deskripsi Objek}

Di wilayah Kelurahan Gegunung, Kecamatan Sumber terdapat beberapa objek yang dikeramatkan masyarakat. Objek-objek tersebut adalah Keramat Pangeran Pasarean dan Ki Buyut Tambak, Ki Buyut Sena, Ki Buyut Timbang, Ki Buyut Srana, Ki Buyut Truna, dan Ki Buyut Klaya. Keramat-keramat tersebut semuanya secara historis berkaitan dengan Pangeran Pasarean. 


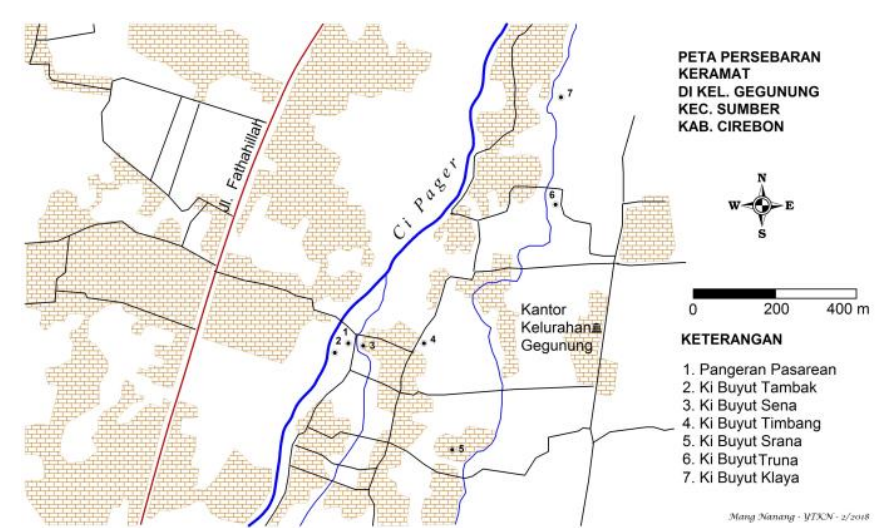

Gambar 2. Peta Persebaran Keramat di Kelurahan Gegunung, Kecamatan Sumber, Kabupaten Cirebon (Sumber: Dokumen Nanang Saptono, 2018)

\section{Keramat Pangeran Pasarean}

Keramat Pangeran Pasarean berada di permukiman penduduk Blok Pasarean di tepi sebelah timur aliran Ci Pager tepatnya berada pada posisi $6^{\circ} 45^{\prime} 1.24 "$ LS dan 108 29'33.41" BT. Di sebelah selatan kompleks merupakan pemakaman umum yang masih difungsikan. Di sebelah timur kompleks keramat terdapat jalan kampung, dan di sebelah utara terdapat PAUD dan rumah tinggal. Di sebelah barat laut terdapat dan museum Pangeran Pasarean dan mushalla. Di museum tersimpan sejumlah benda kuna seperti beberapa naskah kuna, barang-barang tembikar, dan benda pusaka. Di sebelah selatan mushalla atau di sebelah barat kompleks keramat terdapat bangunan terbuka yang disebut Pendopo Agung. Di lokasi ini dahulu merupakan tempat Pangeran Pasarean melakukan musyawarah.

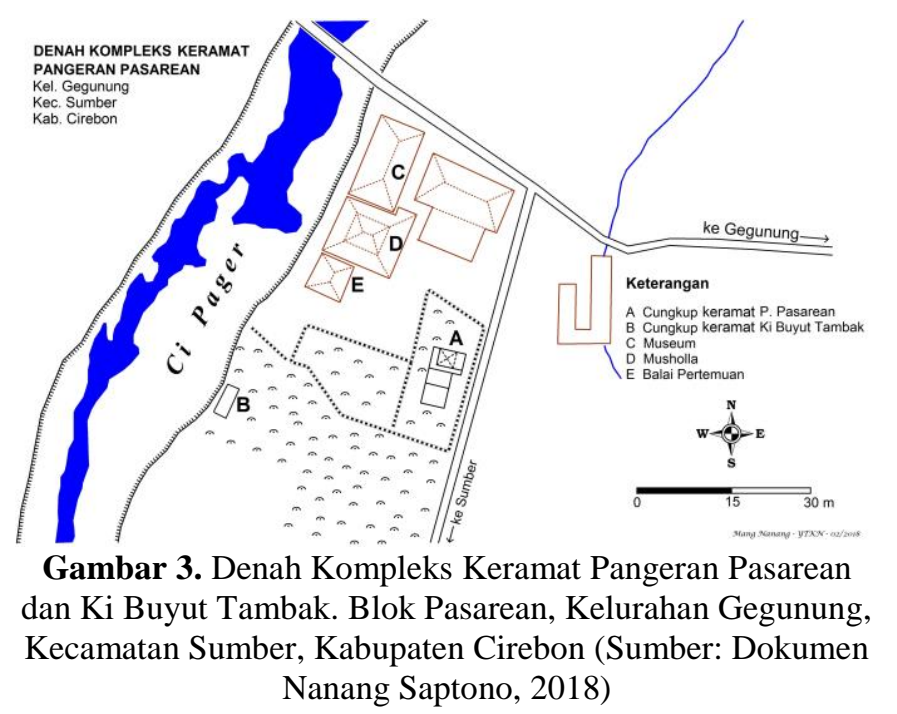

Kompleks keramat dibatasi pagar dari tumpukan batu kali (kuta) dengan tinggi sekitar $50 \mathrm{~cm}$ dan tebal sekitar $40 \mathrm{~cm}$. Denah halaman terbagi dua bagian yaitu bagian barat dan timur. Kedua bagian halaman itu berdenah segi empat. Halaman di bagian barat, pada sisi selatan merupakan kelanjutan dari bagian timur. Pada sisi utara halaman bagian barat terdapat celah untuk keluar masuk ke kompleks keramat. Di depan (di luar) 
celah terdapat gentong dan padasan yang berfungsi sebagai penampung air untuk bersuci. Gentong diletakkan di tanah, sedangkan padasan diletakkan pada batur yang dilindungi semacam cungkup terbuka.

Pada halaman bagian barat terdapat beberapa makam. Makam dilengkapi dengan jirat dari bahan susunan bata dan nisan berbahan bata. Jirat berbentuk empat persegi panjang, semakin ke atas semakin mengecil. Susunan bata pembentuk jirat terdiri lima lapis. Di antara jirat makam terdapat dua batu berdiri berbentuk silinder yang belum bisa diidentifikasi. Pada kuta sisi timur halaman ini terdapat celah yang menghubungkan ke halaman utama kompleks keramat. Di dalam halaman yang berpagar susunan batu terdapat beberapa tumbuhan yang cukup besar. Tumbuhan tersebut diantaranya adalah nagasari (Mesua ferrea L.) dan benda (Artocarpus elasticus). Pada kuta sisi barat ujung utara terdapat potongan nisan (bongpai) dengan aksara Cina yang diletakkan dengan posisi terbalik, bagian atas berada di bawah.

Pada halaman utama juga terdapat beberapa makam. Jirat makam berbentuk persegi panjang semakin ke atas semakin kecil terbuat dari bahan bata. Pada bagian paling atas terdapat lempengan batu berbentuk persegi panjang. Pada beberapa jirat batu tersebut dihias ukiran. Nisan terbuat dari batu berbentuk pipih pada bagian atas berbentuk kurawal. Nisan seperti ini termasuk dalam tipe Demak-Tralaya. Di tengah lahan terdapat bagian yang berpagar tembok bata. Lahan ini terdiri tiga bagian. Pada masing-masing bagian terdapat bangunan cungkup. Bangunan pagar tembok bata dan cungkup merupakan bangunan yang sudah beberapa kali mengalami renovasi. Renovasi terakhir dilakukan pada 1983. Bangunan dicat dengan warna merah bata.

Untuk keluar masuk melalui pintu yang terdapat pada dinding sisi barat bagian tengah. Bangunan pada bagian tengah berfungsi sebagai aula untuk para peziarah. Dinding bangunan sisi barat pada bagian bawah berupa dinding dari bata sedangkan bagian atas berupa ram berbahan kayu. Atap berbentuk tajug dengan penutup berbahan genting. Di sebelah selatan ruang bagian tengah terdapat bangunan cungkup makam berdinding bata. Bagian atap berbentuk tajug dengan penutup berbahan genting.

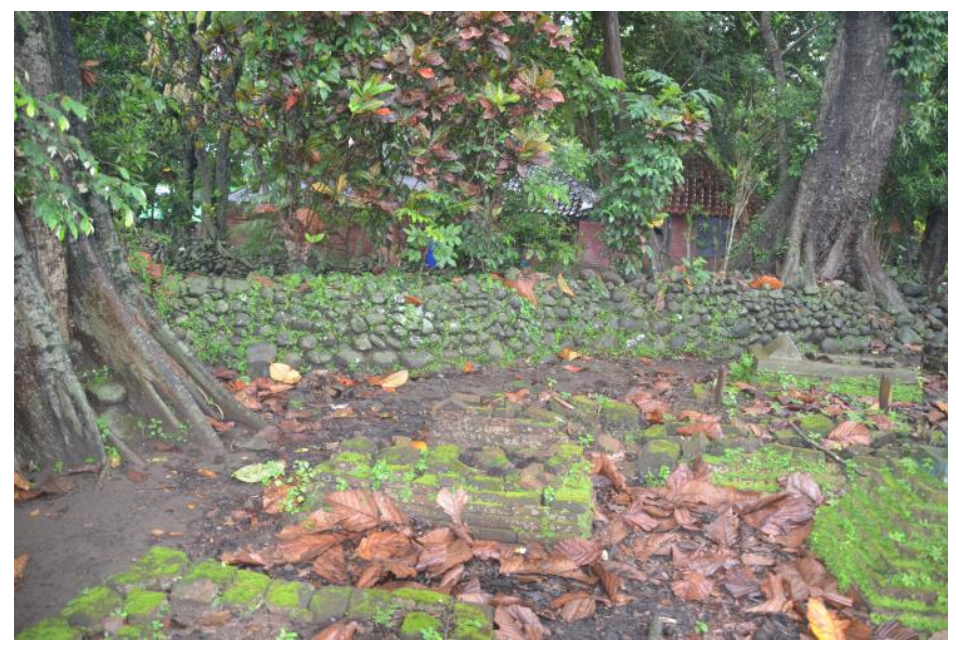

Gambar 4. Pagar susunan batu (kuta) di kompleks Keramat Pasarean (Sumber: Dokumen Nanang Saptono, 2018) 
Halaman utama berada di sebelah utara ruang tengah. Halaman utama berpagar dinding bata. Pada beberapa bagian pagar dihias dengan bentuk candi laras. Untuk keluar masuk ke halaman utama melalui pintu berada pada dinding pagar sisi selatan. Pintu ini menghubungkan antara ruang tengah (aula) dengan cungkup utama. Pintu dilengkapi dua daun pintu berbahan kayu. Pada daun pintu bagian kanan (timur) terdapat hiasan kayu berukir kaligrafi lafal Allah. Pada daun pintu bagian kiri (barat) hiasan kayu berukir kaligrafi berlafal Muhammad.

Pada halaman utama terdapat bangunan cungkup yang posisinya berada pada sudut timur laut halaman, sehingga pada bagian barat dan selatan tersisa bagian halaman terbuka tanpa atap. Pada halaman terbuka ini terdapat objek berupa batu datar yang di atasnya terdapat batu bulat. Bangunan cungkup berdinding bata dengan atap berbentuk tajug tumpang dua. Penutup atap berbahan sirap. Pintu berada pada dinding sisi selatan. Di dalam cungkup terdapat dua makam, makam di sebelah barat adalah makam Pangeran Pasarean dan yang di sebelah timur adalah makam Pangeran Pasindangan. Bagian dalam cungkup utama berlantai tanah/pasir. Kedua jirat berbentuk persegi panjang berbahan bata. Bentuk jirat semakin ke atas semakin kecil. Pada bagian puncak jirat batu. Pada kedua ujung dan bagian tengah terdapat hiasan relief bermotif daun yang distilir. Nisan berbahan batu berbentuk pipih pada bagian puncak meruncing. Pada bagian atas bidang lebar terdapat hiasan medalion.

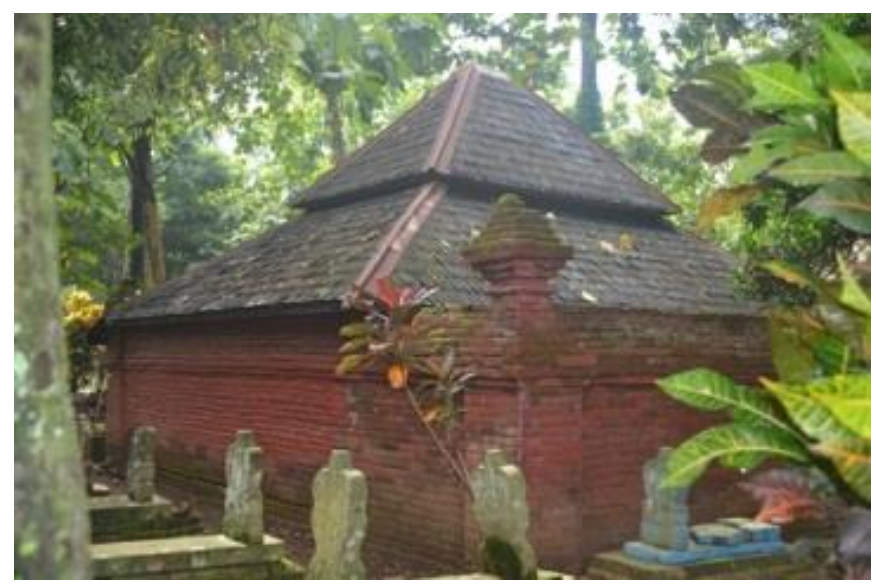

Gambar 5. Cungkup pada halaman utama kompleks Keramat Pasarean (Sumber: Dokumen Nanang Saptono, 2018)

\section{Ki Buyut Tambak}

Keramat Ki Buyut Tambak berada di sisi barat halaman kompleks makam sebelah selatan kompleks keramat Pangeran Pasarean, tepatnya berada pada posisi $6^{\circ} 45^{\prime} 1.60^{\prime \prime}$ LS dan $108^{\circ} 29^{\prime} 32.60^{\prime \prime}$ BT. Di halaman ini terdapat tumbuhan tua seperti misalnya kamboja (Plumeria sp.), selain itu juga banyak tanaman jati (Tectona grandis).

Keramat Ki Buyut Tambak dilengkapi bangunan cungkup semi permanen yang merupakan bangunan baru. Struktur keramat pernah mengalami longsor karena yang posisi keletakannya berada di tepi tebing sungai. Dinding bangunan cungkup bagian 
bawah berupa dinding bata sedangkan bagian atas berupa semacam pagar dari kayu yang disusun dalam posisi tegak. Pintu berada pada dinding sisi timur bagian ujung selatan. Lantai berupa plesteran semen. Atap berbentuk pelana berkonstruksi kayu. Penutup atap dari bahan genteng.

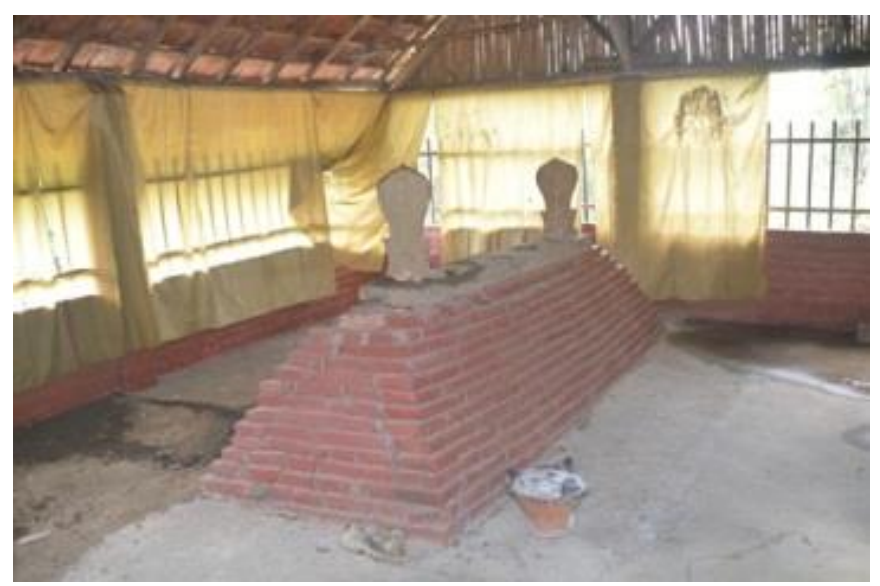

Gambar 6. Jirat dan nisan petilasan Ki Buyut Tambak (Sumber: Dokumen Nanang Saptono, 2018)

Keramat ditandai dengan jirat dan nisan berorientasi utara - selatan. Jirat berbentuk persegi empat berjenjang semakin ke atas semakin kecil. Struktur jirat dari susunan bata sebanyak 14 lapis. Antara lapisan satu dan berikutnya terdapat lapisan spesi berbahan pasir dan semen. Pada bagian puncak jirat terdapat lempengan kayu berhias ukiran dengan motif sulur-suluran. Nisan berupa nisan pipih berbahan kayu berbentuk oval. Pada bagian atas meruncing.

\section{Ki Buyut Sena}

Keramat Ki Buyut Sena berada di sebelah tenggara kompleks Keramat Pangeran Pasarean berjarak lurus sekitar $100 \mathrm{~m}$. Lokasi berada pada sisi barat perkampungan, tepatnya pada posisi $6^{\circ} 45^{\prime} 3.20^{\prime \prime}$ LS dan 108²9'36.00" BT. Di sebelah barat kompleks keramat terdapat aliran sungai kecil (parit). Kondisi topografi miring ke arah barat. Lokasi kompleks keramat juga difungsikan sebagai kompleks pemakaman. Untuk menuju lokasi melalui jalan kampung dan jalan setapak di antara bangunan rumah penduduk.

Keramat Ki Buyut Sena dilengkapi bangunan cungkup permanen yang merupakan bangunan baru. Bangunan cungkup berdenah empat persegi panjang, memanjang arah utara-selatan. Pintu berada di sisi selatan. Dinding berbahan bata tidak berplester. Konstruksi atap berupa atap pelana (atap kampung) dengan penutup berbahan genteng.

Lantai bagian dalam bangunan cungkup berupa lantai tanah. Di dalam cungkup terdapat satu jirat sebagai tanda keramat. Jirat berbentuk persegi panjang semakin ke atas semakin kecil. Bahan pembentuk jirat berupa bata. Antar susunan bata terdapat lapisan spesi tipis. Susunan bata pembentuk jirat terdiri 11 lapis. Pada puncak susunan bata ditutup balok terbuat dari semen berbentuk persegi panjang. Pada kedua ujung 
balok terdapat penanda keramat berupa nisan berbentuk pipih. Bagian puncak nisan berbentuk kurawal. Nisan bagian selatan, pada bagian tengah terdapat hiasan medalion. Pada medalion tersebut terdapat lafal Muhammad. Di sekeliling hiasan medalion dihias dengan motif daun dan sulur-suluran. Nisan bagian utara tidak teramati.

\section{Ki Buyut Timbang}

Keramat Ki Buyut Timbang berada di sebelah timur komplek keramat Pangeran Pasarean berjarak lurus sekitar $187 \mathrm{~m}$. Untuk mencapai lokasi dari kompleks keramat Pangeran Pasarean ke komplek keramat Ki Buyut Timbang melalui jalan kampung. Lahan keramat berupa bukit kecil, berada di sebelah timur jalan kampung. Secara geografis berada pada posisi $6^{\circ} 45^{\prime} 0.90^{\prime \prime}$ LS dan 108 $29^{\prime} 39.50^{\prime \prime}$ BT. Di sebelah barat dan selatan keramat merupakan permukiman sedangkan di sebelah timur dan utara merupakan lahan sawah. Jalan keluar masuk kompleks berada di sudut barat daya lahan. Lahan bagian selatan berteras membentuk empat halaman. Batas antar teras berupa talud yang diperkuat dengan susunan bata. Keramat Ki Buyut Timbang berada di teras ketiga.

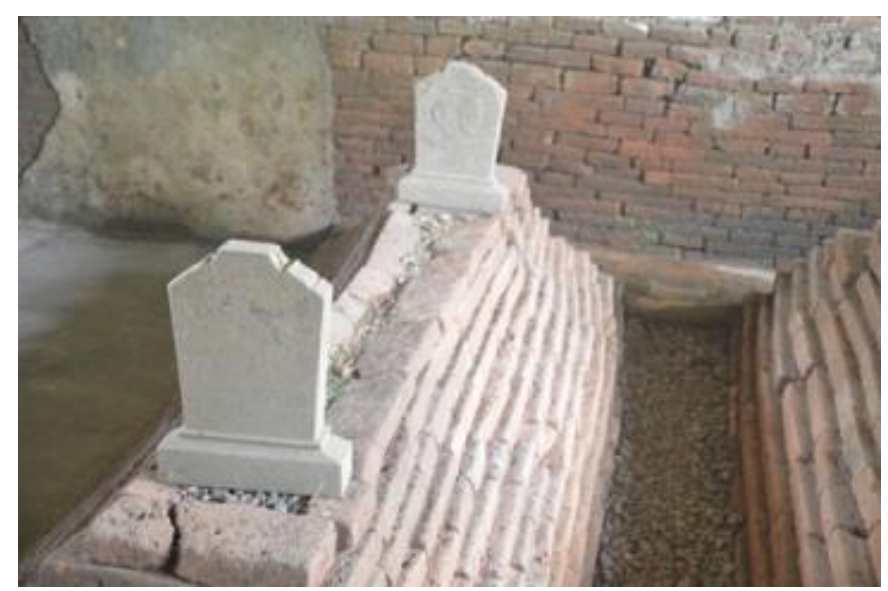

Gambar 7. Bentuk jirat dan nisan di Kompleks Keramat Ki Buyut Timbang (Sumber: Dokumen Nanang Saptono, 2018)

Tanda keramat dilengkapi bangunan cungkup yang bagian depannya (selatan) merupakan bagian terbuka berlantai plesteran semen. Di sebelah utara bagian ini terdapat ruangan berdinding bata tidak berplester. Atap berbentuk atap pelana (atap rumah kampung) dengan penutup atap berbahan genteng. Bangunan ini merupakan bangunan baru.

Di dalam ruangan yang dibatasi dinding bata terdapat tanda keramat berupa dua jirat yang dilengkapi nisan. Jirat tersebut merupakan tanda keramat Ki Buyut Timbang dan Paku Alam. Jirat berbentuk empat persegi panjang, terbuat dari susunan bata terdiri 13 lapis. Susunan bata ini semakin ke atas semakin kecil. Pada bagian puncak dilengkapi nisan pipih tipe Demak-Tralaya. Pada bagian depan nisan terdapat hiasan medalion. Nisan terbuat dari bahan batu pasir.

Di luar bangunan cungkup pada halaman lahan merupakan kompleks pemakaman. Pada teras paling atas merupakan lahan lapang terdapat beberapa bongkah batu. Kumpulan bongkah batu terdapat di bagian sudut baratdaya halaman teras teratas 
dan di bagian tengah halaman. Pada bagian tengah halaman juga terdapat lubang berbentuk bundar menyerupai sumur.

\section{Ki Buyut Srana}

Di sebelah tenggara kompleks keramat Pangeran Pasarean berjarak sekitar 340 m terdapat kompleks keramat Ki Buyut Srana. Kompleks keramat berada pada semacam lereng bukit kecil dengan topografi miring ke arah utara. Secara geografis lahan situs berada pada posisi $6^{\circ} 45^{\prime} 9.50^{\prime \prime}$ LS dan 108²9'41.80" BT. Untuk menuju lokasi dari kompleks keramat Pangeran Pasarean dapat melalui jalan kampung. Di lokasi kompleks keramat Ki Buyut Srana, jalan kampung berada di sebelah utara lahan situs. Jalan kampung tersebut juga menghubungkan beberapa perkampungan yang berada di sebelah barat laut kompleks keramat hingga sebelah utara dan timur laut.

Kondisi lahan situs berupa kompleks pemakaman umum. Gerbang keluar masuk berada di sisi utara lahan. Topografi lahan miring, bagian selatan lebih tinggi dari pada bagian utara. Dengan kondisi yang demikian lahan kompleks dibentuk secara berundak. Pada bagian tengah terdapat lahan yang berpagar dinding bata. Lahan ini merupakan bagian inti keramat Ki Buyut Srana. Pagar dinding bata berdenah segi empat. Tinggi pagar berkisar $1 \mathrm{~m}$, pada setiap sudut terdapat hiasan candi laras. Gerbang berada di sisi selatan berupa semacam gapura bentar. Di sebelah selatan kompleks keramat Ki Buyut Srana terdapat bangunan terbuka untuk sarana peziarah. Bangunan ini merupakan bangunan baru.

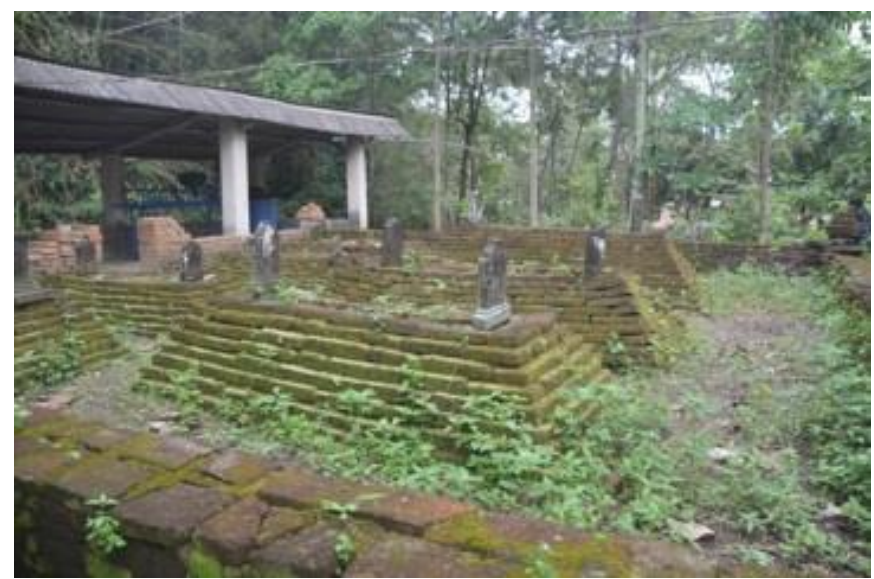

Gambar 8. Beberapa makam di Kompleks Keramat Ki

Buyut Srana (Sumber: Dokumen Nanang Saptono, 2018)

Di bagian dalam halaman kompleks keramat Ki Buyut Srana terdapat 7 penanda keramat berbentuk jirat dilengkapi nisan. Susunan penanda keramat terdiri 2 sap (baris). Sap bagian utara terdiri 3 penanda keramat dan sap bagian selatan terdiri 4 penanda keramat. Jirat berbentuk segi empat panjang dari susunan bata, semakin ke atas semakin kecil. Susunan bata pembentuk jirat pada masing-masing penanda keramat bervariasi antara 7 hingga 10 lapis bata. Nisan pada umumnya berbentuk nisan pipih tipe DemakTralaya terbuat dari bahan batu andesit. 


\section{Ki Buyut Truna}

Keramat Ki Buyut Truna berada di sebelah timur laut kompleks keramat Pangeran Pasarean berjarak lurus sekitar $620 \mathrm{~m}$. Lokasi berada di antara lahan sawah, tepatnya pada posisi $6^{\circ} 44^{\prime} 50.10^{\prime \prime}$ LS dan 108 $29 ' 50.20^{\prime \prime}$ BT. Lahan kompleks keramat Ki Buyut Truna memanjang arah utara-selatan dengan luas sekitar $3000 \mathrm{~m}^{2}$ atau 0,3 hektar, topografi lahan miring ke arah utara (bagian utara lebih rendah daripada bagian selatan). Lahan ini berfungsi sebagai lahan pemakaman umum terutama bagi masyarakat setempat. Di sebelah barat lahan terdapat aliran sungai kecil (parit). Di selah utara terdapat jalan yang menghubungkan perkampungan di sebelah barat kompleks keramat dengan jalan raya desa di sebelah timur.

Keramat Ki Buyut Truna berada pada ujung utara lahan. Keramat dilengkapi bangunan permanen berupa bangunan terbuka tanpa dinding dilengkapi atap. Lantai dari bahan keramik. Tiang penyangga atap dari bahan beton bertulang. Bagian atap berupa konstruksi kayu dengan penutup berbahan asbes. Pada bangunan ini terdapat 2 penanda keramat berbentuk jirat dilengkapi nisan, berarientasi utara-selatan. Jirat dari susunan bata berbentuk persegi empat panjang. Susunan bata terdiri 8 lapis, semakin ke atas semakin kecil. Jirat di bagian timur dilengkapi 1 nisan di ujung utara. Nisan berbentuk pipih persegi. Jirat di bagian barat juga dilengkapi 1 nisan yang berada di ujung utara. Nisan pada jirat penanda keramat ini berbentuk nisan pipih pada bagian atas meruncing. Pada bagian tengah terdapat hiasan medallion. Nisan semacam ini merupakan nisan tipe Demak-Tralaya.

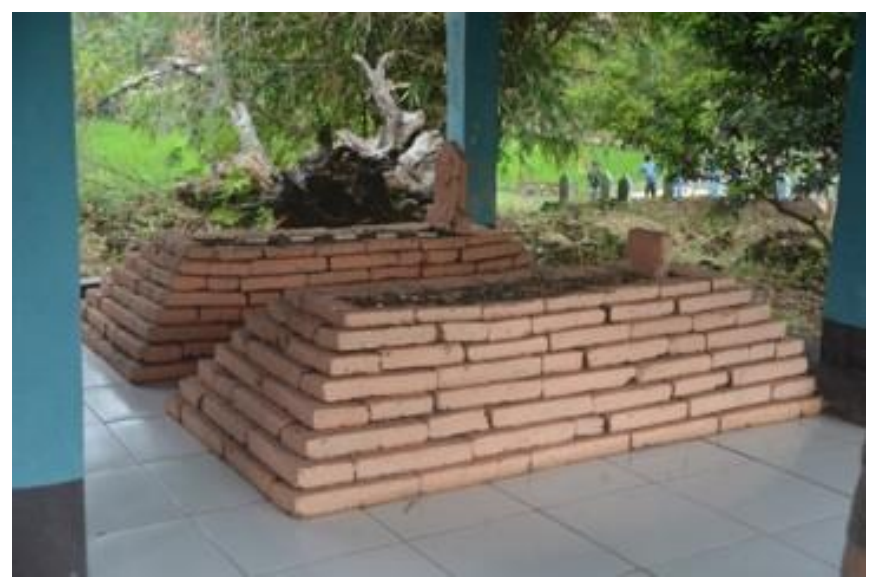

Gambar 9. Jirat dan nisan di Kompleks Keramat Ki Buyut Truna Kelurahan Gegunung, Kecamatan Sumber, Kabupaten Cirebon (Sumber: Dokumen Nanang Saptono, 2018)

\section{Ki Buyut Klaya}

Lokasi keramat Ki Buyut Klaya merupakan yang terjauh dari kompleks keramat Pangeran Pasarean. Keramat Ki Buyut Klaya berada di sebelah timur laut berjarak lurus sekitar $790 \mathrm{~m}$. Lahan keramat berada di sebelah timur permukiman. Antara lahan keramat dan permukiman terdapat aliran sungai atau saluran irigasi. Lahan keramat berada pada posisi yang lebih tinggi dari pada permukiman. Untuk menuju kompleks 
keramat melewati jalan kampung. Secara geografis, keramat Ki Buyut Klaya berada pada posisi 6 44'41.90" LS dan 108²9'50.30" BT.

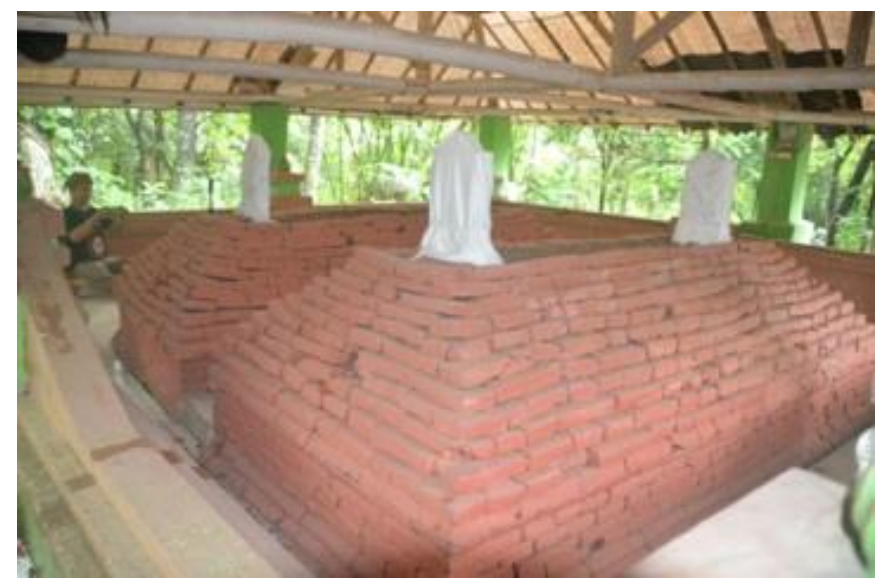

Gambar 10. Jirat di Kompleks Keramat Ki Buyut Klaya (Sumber: Dokumen Nanang Saptono, 2018)

Sebagaimana kompleks keramat yang lain, lahan kompleks keramat Ki Buyut Klaya merupakan pemakaman umum. Di tengah lahan terdapat bangunan permanen dengan dinding hanya setengah sehingga terkesan sebagai pagar keliling. Pada pagar/dinding terdapat kolom (tiang) penyangga atap. Lantai dari bahan keramik berwarna putih. Dinding/pagar dan kolom pada saat ini dicat warna hijau muda. Bagian atap merupakan atap dengan konstruksi kayu dan bambu. Penutup atap dari bahan fiberglass bening sehingga sinar matahari dapat memberikan penerangan pada ruangan. Bangunan ini merupakan bangunan baru.

Di dalam bangunan terdapat jirat penanda keramat berjumlah dua. Masingmasing jirat terbuat dari susunan bata. Pada bagian bawah jirat, yaitu hingga lapisan ke9 berbentuk persegi. Selanjutnya semakin ke atas semakin kecil. Bagian ini terdiri 10 lapisan. Nisan berbentuk nisan pipih. Bahan dan detail nisan tidak teramati karena dibungkus kain putih. Secara umum nisan keramat Ki Buyut Klaya berupa nisan tipe Demak-Tralaya.

\section{Jejak-jejak Permukiman}

Keramat Pangeran Pasarean dan beberapa keramat di sekitarnya secara administratif berada di wilayah Kelurahan Gegunung, Kecamatan Sumber, Kabupaten Cirebon. Geomorfologi kawasan ini berupa pedataran yang diselingi pedataran bergelombang dengan topografi miring ke arah utara. Di sebelah barat terdapat aliran Ci Pager dan di sebelah timur terdapat aliran Ci Kedungpane. Kawasan selatan Cirebon sudah sejak lama menjadi kawasan yang cukup penting bagi penguasa-penguasa wilayah pada zamannya. Historiografi lokal Cirebon seperti Carita Purwaka Caruban Nagari dan tradisi lisan menyebutkan bahwa di wilayah Cirebon terdapat beberapa kerajaan kecil. Kerajaan-kerajaan kecil dimaksud adalah Kerajaan Indraprahasta, Keraton Carbon Girang, Singapura, dan Japura. Kerajaan Indraprahasta berdiri pada sekitar 363 - 723 M, dipimpin oleh Ki Gedeng Kasmaya. Lokasi keraton diperkirakan 
di Desa Sarwadadi, Kecamatan Sumber. Setelah Kerajaan Indraprahasta runtuh muncul kerajaan yang didirikan oleh Ki Gedeng Carbon Girang anak Ki Gedeng Kasmaya dengan keraton di Carbon Girang. Kerajaan Singapura merupakan kerajaan bawahan Galuh berlokasi di sebelah utara Giri Amparan Jati. Sedangkan Japura wilayahnya mencakup wilayah yang sekarang secara administratif merupakan wilayah Desa Japura Kidul, Japura Lor, dan Desa Astanajapura (Hardjasaputra dan Haris, 2011: 35). Mengenai Japura, Tomé Pires mengabarkan bahwa negeri itu berbatasan dengan Cirebon dan Losari. Penduduknya lebih dari 2.000 jiwa tersebar di desa-desa. Penguasa Negeri Japura adalah Pate Rodim, sedangkan Losari dikuasai oleh Pate Codia. Di Japura banyak menghasilkan beras, lilin, madu, dan bahan makanan lainnya. Di situ terdapat pelabuhan, jika menyusuri sungai akan sampai ke kota (Cortesao, 1967: 183184).

Pada masa Kerajaan Sunda kawasan di selatan Cirebon dan kawasan timur Jawa Barat sekarang, sudah menjadi perhatian pusat yang pada waktu itu berada di sekitar Bogor sekarang. Bukti kekuasaan Kerajaan Sunda di kawasan timur adalah prasasti Huludayeuh yang ditemukan di Desa Cikalahang, Kecamatan Sumber. Prasasti diperkirakan ditulis oleh Raja Surawisesa (1521 - 1535) berisi tentang usaha kebajikan mensejahterakan bumi yang dilakukan oleh Ratu Purana Sri Baduga Maharaja (1481 1521) (Djafar, 1994: 199). Beberapa bukti arkeologis berupa arca-arca tipe Polinesia yang mengandung ciri kuat agama Hindu yang ditemukan di Pejambon, Kecamatan Sumber menunjukkan bahwa wilayah Cirebon merupakan kekuasan Kerajaan Sunda (Widyastuti, 2002). Wilayah di timur ini juga disebutkan dalam berita asing dari Portugis. Tomé Pires Kerajaan Sunda mempunyai enam pelabuhan penting di pesisir utara. Pelabuhan paling timur adalah Chemano yang sekarang bernama Indramayu. Chemano merupakan pelabuhan yang cukup ramai meskipun kapal besar tidak dapat berlabuh di sini. Di kota ini sudah banyak warga muslim. Para pedagang menjalin hubungan hingga seluruh Jawa. Pelabuhan ini merupakan batas timur Kerajaan Sunda (Cortesao, 1967: 173).

Di dalam Carita Parahyangan, Kerajaan Sunda yang berpusat di Pakwan Pajajaran membangun jalan darat menghubungkan seluruh wilayah kekuasaannya. Jalan darat itu berpusat di Pakwan Pajajaran menuju ke arah timur dan barat. Jalan yang menuju ke timur melalui Cileungsi dan Cibarusah hingga di Tanjungpura yang terletak di tepi Ci Tarum, Karawang. Selanjutnya dari Tanjungpura menuju Cikao dan Purwakarta, dan berakhir di Karangsambung di tepi Ci Manuk. Selanjutnya jalan tersebut bercabang ke arah timur dan selatan. Jalan yang ke arah timur sampai Cirebon lalu berbelok ke selatan melalui Kuningan dan berakhir di Galuh atau Kawali. Sedangkan jalan yang ke arah selatan melalui Sindangkasih dan Talaga dan berakhir juga di Kawali (Poesponegoro dan Notosusanto, 2009: 420). Berdasarkan gambaran fakta sejarah tersebut, kawasan Cirebon termasuk daerah selatan sudah menjadi kawasan penting bagi Kerajaan Sunda.

Kawasan di sekitar Desa Gegunung sekarang, dalam historiografi Kesultanan Cirebon erat kaitannya dengan Pangeran Pasarean, putra Syaikh Syarif Hidayatullah, 
atau yang dikenal dengan nama Sunan Gunung Jati. Pangeran Pasarean lahir pada tahun 1495 M. Ketika Sunan Gunung Jati memusatkan perhatian pada penyebaran Islam, Pangeran Pasarean mendapat tugas mengurus pemerintahan. Salah satu tugas dalam mengurus pemerintahan adalah membuat tapal batas antara Galuh dan Cirebon. Selama menjalankan tugas ini, Pangeran Pasarean beserta pendampingnya bermukim di Gegunung. Lokasi pemukiman tersebut sekarang dikenal sebagai keramat yang ditandai dengan struktur dan bangunan sebagaimana makam tokoh-tokoh Islam. Adapun objekobjek keramat tersebut adalah Keramat Pangeran Pasarean, Keramat Ki Buyut Tambak, Ki Buyut Sena, Ki Buyut Timbang, Ki Buyut Srana, Ki Buyut Truna, dan Ki Buyut Klaya. Aktivitas Pangeran Pasarean di Gegunung mungkin pada masa Kerajaan Sunda diperintah oleh Ratu Purana Sri Baduga Maharaja (1481 - 1521). Pada waktu itu di kawasan timur merupakan wilayah Galuh sebagai penguasa di bawah Kerajaan Sunda. Mengenai tapal batas Cirebon, beberapa sumber menyebutkan berbeda-beda. Babad Cerbon dan Purwaka Caruban Nagari menerangkan bahwa batas wilayah Cirebon adalah Ci Pamali di sebelah timur, Cigugur, Kuningan di sebelah selatan, Pegunungan Kromong di sebelah barat, dan daerah Junti, Indramayu di sebelah utara (Ambary, 1998: 107). Catatan Thomas Stamford Raffles menyebutkan bahwa wilayah Cirebon di sepanjang pesisir utara meliputi Karawang, Ciasem, Pamanukan, Kandangaur, dan Indramayu, sedangkan yang berada di sebelah selatan terdiri Cianjur, Bandung, Sumedang, Limbangan, dan Sukapura (Raffles, 2008: 5).

Secara arkeologis, objek-objek yang terdapat di lokasi Keramat Pangeran Pasarean menunjukkan tinggalan budaya masyarakat. Struktur pagar (kuta) dari susunan batu merupakan tradisi yang sudah dikenal lama di kawasan Jawa Barat. Beberapa objek arkeologis di situs Karangkamulyan, situs Bojong Salawe, dan beberapa situs lainnya di Ciamis merupakan contoh struktur lama tradisi kuta batu di Jawa Barat. Selain itu, beberapa material penyusun struktur jirat dan nisan juga menunjukkan merupakan benda arkeologis yang cukup tua.

Dilihat dari aspek permukiman, objek keramat di kawasan Keramat Pangeran Pasarean menggambarkan pola pemukiman yang keletakannya sangat ideal. Aliran $\mathrm{Ci}$ Pager dan Ci Kedungpane secara alami berperan sebagai batas wilayah dan sekaligus memberikan berbagai manfaat. Pada masa Kerajaan Sunda Pajajaran, Ci Pager dianggap sebagai Sungai Gangga. Pada waktu itu Ci Pager dan Ci Kedungpane juga berfungsi sebagai prasarana transportasi (Rusyanti, 2010). Ci Pager yang dijadikan batas antara Cirebon dan Galuh juga dapat berfungsi sebagai pertahanan wilayah. Secara praktis dengan adanya dua aliran sungai tersebut, kebutuhan terhadap air bagi masyarakat dapat tercukupi.

Objek amatan di Desa Gegunung kebanyakan berupa makam/petilasan. Bentukbentuk makam/petilasan tersebut cenderung sebagai ekspresi penghormatan kepada tokoh yang sangat berpengaruh. Dalam budaya Jawa penghormatan kepada leluhur masih sangat kental sehingga makam disebut pasarean (tempat tidur) atau juga kasuyatan (ketenangan), terlebih apabila hal itu ditujukan kepada para sultan, wali, dan tokoh-tokoh penyebar Islam (Ambary, 1998: 98). Pada beberapa lokasi terdapat bekas 
di mana seseorang tokoh melakukan aktivitas penting. Pada lokasi tersebut kemudian dibuatkan objek sebagaimana makam yang kemudian dikenal dengan sebutan petilasan.

Berdasarkan pengamatan terhadap objek-objek yang terdapat di Keramat Pangeran Pasarean, Keramat Ki Buyut Tambak, Ki Buyut Sena, Ki Buyut Timbang, Ki Buyut Srana, Ki Buyut Truna, dan Ki Buyut Klaya kebanyakan menunjukkan objek baru. Bangunan cungkup hampir seluruhnya merupakan bangunan baru. Struktur jirat dan nisan juga menunjukkan objek yang tidak begitu tua. Namun secara arkeologis lokasi-lokasi tersebut merupakan titik-titik penting bagi rekonstruksi permukiman pada waktu itu dan sangat penting bagi rekonstruksi sejarah budaya. Berkaitan dengan aspek proses perubahan budaya, terdapat permasalahan sejak kapan muncul tradisi menandai petilasan tokoh dalam bentuk struktur jirat dan nisan. Permasalahan perlu dikaji lebih dalam lagi mengingat proses perubahan seperti ini juga terjadi di lokasi lain, seperti makam keramat Kuwu Sangkan di Desa Cirebon Girang, Kecamatan Talun, Cirebon; makam Syekh Datuk Kahfi di Desa Pabean Ilir, Kecamatan Pasekan, Kabupaten Indramayu; dan makam Ratu Nyi Rambut Kasih di Kelurahan Sindangkasih, Majalengka.

\section{SIMPULAN}

Beberapa situs arkeologis di Gegunung yang berupa makam atau petilasan pada mulanya merupakan permukiman atau tempat tinggal tokoh-tokoh. Makam atau petilasan yang terlihat sekarang ditandai dengan bentuk jirat dan nisan serta dilengkapi bangunan cungkup. Pemukiman-pemukiman tersebut membentuk pola memusat yang terpusat di kompleks Keramat Pangeran Pasarean. Di kompleks Keramat Pangeran Pasarean terdapat tinggalan arkeologis yang sangat penting untuk dilindungi dan dilestarikan. Objek tersebut antara lain berupa struktur pagar batu dan beberapa objek artefaktual lainnya. Oleh karena itu mengingat arti pentinggnya tinggalan dilihat dari sudut pandang Undang-undang Cagar Budaya maka perlu dilakukan pengkajian lebih dalam lagi terutama pada aspek kesejarahan. Dinas yang berkompeten perlu segera melakukan registrasi dan selanjutnya penetapan sebagai Cagar Budaya atau situs budaya.

\section{Terimakasih Kepada:}

Mama R. Hasan Ashari, Ketua Yayasan Pangeran Pasarean yang telah menyediakan fasilitas selama pengumpulan data. Pandu Radea, Toto Taofik, Tizi Rakyan Zarathusta, dan Hamdan Hidayatulloh rekan-rekan Yayasan Tapak Karuhun Nusantara yang telah membantu dalam pengumpulan data di lapangan.

\section{DAFTAR PUSTAKA}

Ambary, H. M. (1998). Menemukan Peradaban: Arkeologi dan Islam di Indonesia. Jakarta: Pusat Penelitian Arkeologi Nasional.

Ashari, R. H. (2018). Sejarah Situs Pangeran Pasarean. Cirebon: Yayasan Pangeran Pasarean. 
Cortesao, A. (1967). The Suma Oriental of Tome Pires. Nendelnd iechtenstein: Kraus Reprint Limited.

Djafar, H. (1994). Prasasti Huludayeuh. Berkala Arkeologi Edisi Khusus: Evaluasi Data Dan Interpretasi Baru Sejarah Indonesia Kuna, 197-199.

Hardjasaputra, A. S., dan Haris, T. (2011). Cirebon Dalam Lima Zaman (Abad ke-15 Hingga Pertengahan Abad ke-20). Bandung: Dinas Pariwisata dan Kebudayaan Provinsi Jawa Barat.

Krom, N. J. (1915). Rapporten van den Oudheidkundigen Dienst in Nederlandsch-Indie 1914. Batavia: Albrecht \& Co.

Poesponegoro, M. D., dan Notosusanto, N. (2009). Sejarah Nasional Indonesia II, Zaman Kuno. Jakarta: Balai Pustaka.

Raffles, T. S. (2008). The History of Java. (H. Simanjuntak dan R. B. Santosa, Eds.). Yogyakarta: Narasi.

Rusyanti. (2010). Sungai Sebagai Jalur Distribusi Lokal di Cirebon pada Abad ke-14 18 M. In N. T. Harkantiningsih (Ed.), Perdagangan dan Pertukaran Masa Prasejarah - Kolonial (pp. 65-80). Jatinangor: Alqaprint.

Suhadi, M., dan Saptono, N. (1994). Laporan Penelitian Arkeologi di Kabupaten Cirebon, Jawa Barat. Bandung.

Sunarto, E., Saptono, N., Boedi, O. B., dan Rif'ati, H. F. (2011). Profil Peninggalan Sejarah dan Purbakala di Jawa Barat. Bandung: Dinas Pariwisata dan Kebudayaan Provinsi Jawa Barat.

Widyastuti, E. (2002). Arca-arca Tipe Pajajaran di Pejambon. In A. A. Munandar (Ed.), Jelajah Masa Lalu (pp. 75-85). Bandung: Ikatan Ahli Arkeologi Indonesia. 
JURNAL PANALUNGTIK - Vol. 2, No. 2, Desember 2019 